\title{
The Distribution, Biological and Ecological Features of Typha shuttleworthii (Typhaceae) in the Vyatka-Kama Cis-Urals, Russia
}

\author{
Olga A. Kapitonova, Guzel R. Platunova, Vladimir I. Kapitonov \\ Udmurt State University, Izhevsk, Russia \\ Email: kapoa@udsu.ru \\ Received 15 January 2015; accepted 31 January 2015; published 3 February 2015 \\ Copyright (C) 2015 by authors and Scientific Research Publishing Inc. \\ This work is licensed under the Creative Commons Attribution International License (CC BY). \\ http://creativecommons.org/licenses/by/4.0/

(c) (i) Open Access

\begin{abstract}
Typha shuttleworthii is the semi-aquatic plant in the modern areal which embraces mainly the ocean districts of Europe. The eastern border of the area of this species is located in Eastern Europe on the territory of Vyatka-Kama Cis-Urals (VKCU). Almost everywhere species is considered rare and is included in the Red Data Books in many European countries. However, on the territory of Russia, $T$. shuttleworthii is not protected. The rarity of this species makes it necessary to study its natural populations for their protection. In the paper, we present the materials on some biological and ecological features of the Typha shuttleworthii, growing on the territory of VyatkaKama Cis-Urals, where the species is represented by its extreme eastern populations. This species is offered to the protection on the territory of the European part of Russia within the Republic of Tatarstan and Udmurtia.
\end{abstract}

\section{Keywords}

Typha shuttleworthii, Cattails, Macrophyte, Vyatka-Kama Cis-Urals, Udmurt Republic, Tatarstan, Russia

\section{Introduction}

Typha shuttleworthii W.D.J. Koch et Sond. relates to species of typical section of genus Typha L. (Typhaceae Juss.) [1] [2]. The modern areal of species embraces the ocean districts of Europe and includes the countries of the Medium and Central Europe and Mediterranean, quasi-the countries of Eastern Europe [2] [3]. Almost 
everywhere species is considered rare. It is extinct in Hungary, included in the Red Data Books or Red Lists in many European countries: Slovakia, Liechtenstein, Germany, Switzerland, Austria, Greece, Bulgaria, Czech Republic, Serbia [3]-[8]. This species was recently marked in Poland, where it is considered as a vulnerable plant species [8]. At the same time, in European Red List of Vascular Plants needed protection, it is marked as a species for which there is no sufficient information ("Data Deficient") [9]. The species is known also from Belarus [10]; it is given to Ukrainian steppe flora [11]. In Russia T. shuttleworthii is considered sufficiently common species in some Western regions and is known from Moscow and Kaluga regions, from Krasnodar Territory, Crimea and some areas of Ciscaucasia [11]-[13]. The extreme eastern populations in area of T. shuttleworthii are known from the territory of Vyatka-Kama Cis-Urals (VKCU) within the Republic of Udmurtia and Tatarstan, where the growing of this cattail for the first time was marked by us in 2006 [14] [15]. Afterwards a small population of the species was found in the city Izhevsk [16]. In connection with the feature of distribution of $T$. shuttleworthii and its rarity, it is interesting to study some biological and ecological characteristics of plants of this species growing on the border of the area.

\section{Material and Methods}

Two of three populations of $T$. shuttleworthii, known at present on the territory VKCU were studied (Figure 1). One of them (№1) is located $5 \mathrm{~km}$ south from village Muvazhi, Alnashsky district, Udmurt Republic ( 56 $06^{\circ} \mathrm{N}$, $52^{\circ} 42^{\prime} \mathrm{E}$ ) and occupies the coastal shallow water of a small pond on the river Golyushurminka. The population is composed of two plots an area of $105 \mathrm{~m}^{2}$ and $70 \mathrm{~m}^{2}$ spaced at right angle, repeating the shape of the coastline.

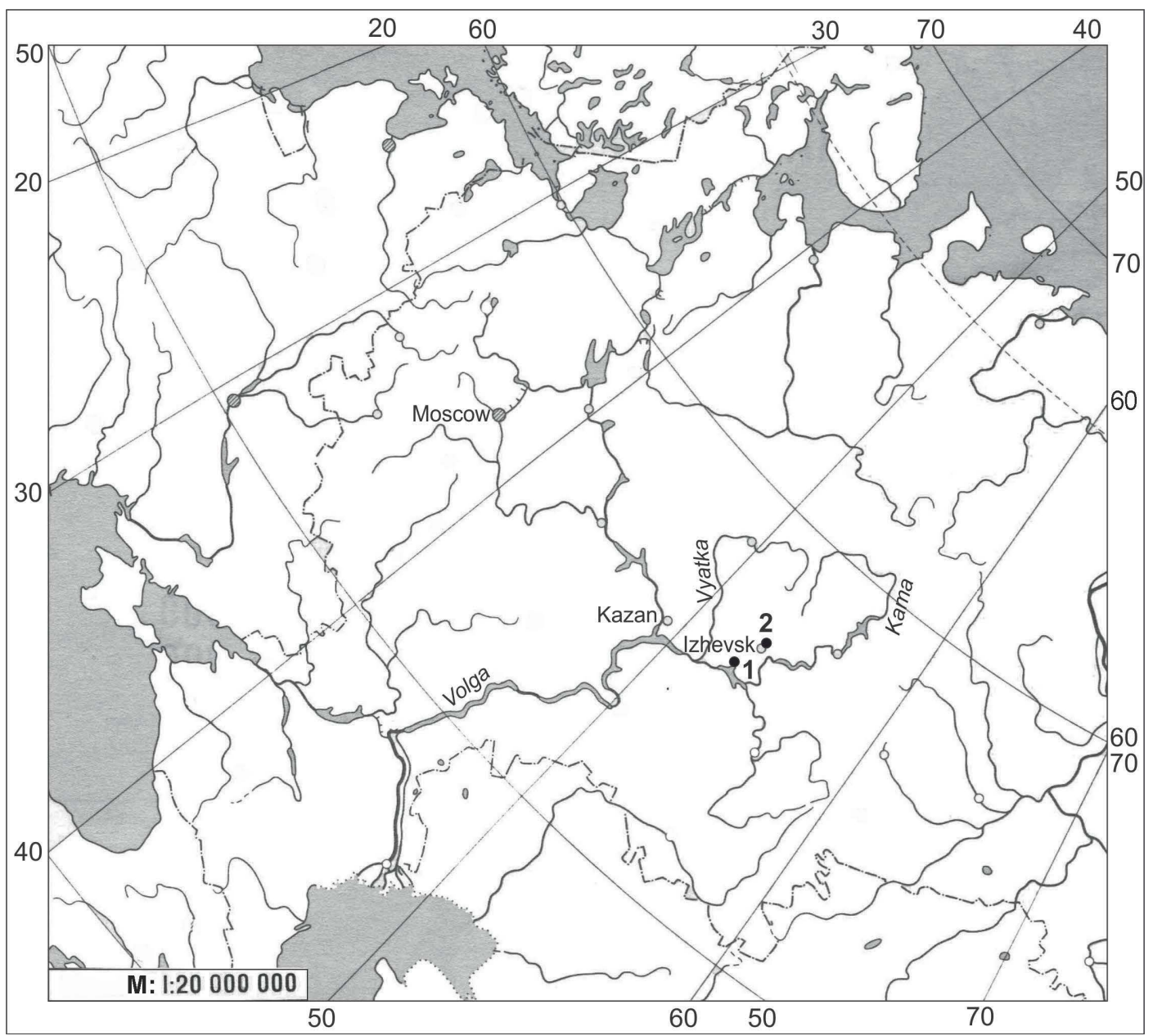

Figure 1. Distribution of Typha shuttleworthii W.D.J. Koch et Sond. in VKCU. The numbers of examined populations are marked. 
Second population (№2) is located in the city of Izhevsk in the neighborhood of the Botanical Garden of Udmurt State University $\left(\sim 56^{\circ} 55^{\prime} \mathrm{N}, 53^{\circ} 15^{\prime} \mathrm{E}\right)$ and being on the damp bottom of the drainage channel.

On sample plots within populations the species composition of vascular plants was identified, general projective cover and projective cover of the marked species on the Braun-Blanquet cover-abundance scale were reported. On the living plants the morphological parameters were measured having diagnostic value. The aboveground biomass of plants was studied in 2008 by the example of population №1. The population №2 at the time of research was strongly rarefied, therefore in order to preserve it was not used for the study of biomass. Crude, air-dry and absolutely-dry biomass was measured to the nearest $0.01 \mathrm{~g}$ on the technical scales "ВЛКТ-500". То air-dry state the plant was adjusted in the open air on the shaded conditions, and then was ground and dried to absolutely-dry state at the temperature of $105^{\circ} \mathrm{C}$.

\section{Results and Discussion}

Within the main area $T$. shuttleworthii ecotopic connected with natural and artificial watered habitats. On the territory of the VKCU species is found in secondary habitats represented shallows of artificial reservoirs (small ponds) and the bottom of the drainage channels. The communities with dominance of $T$. shuttleworthii were low taxonomic diversity (Table 1). General projective cover was varied between $50 \%-100 \%$, the cover-abundance of $T$. shuttleworthii within phytocenoses changed from 2 to 4 on a scale of Braun-Blanquet, the ratio of the number of generative to vegetative shoots was 2:3.

Crude aboveground biomass of cattail at the end of July 2008 in the population №1 was on average 4.85 $\mathrm{kg} / \mathrm{m}^{2}$, air-dry- $1.96 \mathrm{~kg} / \mathrm{m}^{2}$, absolutely-dry- $1.90 \mathrm{~kg} / \mathrm{m}^{2}$.

The results of the study of morphometric parameters of the population №1 are presented in Table 2. According to obtained data, the plants of this species in the territory of the VKCU have reproductive shoots 1.07 - 1.62 m height with 7 - 8 light-green leaves. The leaves usually are somewhat longer than the flowering shoots. The width of the leaves varies widely, however, leaves of the reproductive shoots are somewhat narrower. The female inflorescence is cylindrical, in the flowering period it is green or dark-green, during the fructification

Table 1. Plant communities with dominance of Typha shuttleworthii W.D.J. Koch et Sond. in VKCU.

\begin{tabular}{|c|c|c|c|c|c|}
\hline № of description & 1 & 2 & 3 & 4 & Constancy \\
\hline Descriptions area, $\mathrm{m}^{2}$ & 4 & 4 & 4 & 3 & \\
\hline General projective cover (\%) & 100 & 90 & 90 & 50 & \\
\hline Depth $(\mathrm{m})$ & 0.1 & 0.1 & 0.2 & 0 & \\
\hline Water transparency, cm & 0.1 & 0.1 & 0.2 & 0 & \\
\hline Velocity of flow, metre per second & 0 & 0 & 0 & 0 & \\
\hline Type of the ground or substrate & Silt & Silt & Silt & Clay & \\
\hline Number of species & 6 & 5 & 4 & 9 & \\
\hline Typha shuttleworthii W.D.J. Koch et Sond. & 4 & 4 & 3 & 2 & $\mathrm{~V}^{2-4}$ \\
\hline Lemna minor L. & 1 & 1 & 1 & . & $\mathrm{IV}^{1}$ \\
\hline Spirodela polyrhiza (L.) Schleid. & 1 & 1 & 1 & . & $\mathrm{IV}^{1}$ \\
\hline Eleocharis palustris (L.) Roem. et Schult & 2 & . & 2 & . & $\mathrm{III}^{2}$ \\
\hline Alisma plantago-aquatica L. & . & 1 & . & + & $\mathrm{III}^{+-1}$ \\
\hline Typha angustifolia L. & . & + & $\cdot$ & $\cdot$ & $\mathrm{I}^{+}$ \\
\hline Typha latifolia L. & + & . & . & . & $\mathrm{I}^{+}$ \\
\hline Scirpus sylvaticus L. & + & . & . & · & $\mathrm{I}^{+}$ \\
\hline Equisetum arvense L. & . & . & $\cdot$ & + & $\mathrm{I}^{+}$ \\
\hline Tussilago farfara $\mathrm{L}$. & . & . & $\cdot$ & + & $\mathrm{I}^{+}$ \\
\hline Cirsium setosum (Willd.) Bess. & . & $\cdot$ & $\cdot$ & + & $\mathrm{I}^{+}$ \\
\hline Ranunculus repens L. & . & . & . & + & $\mathrm{I}^{+}$ \\
\hline Deschampsia cespitosa (L.) Beauv. & . & . & . & + & $\mathrm{I}^{+}$ \\
\hline Salix triandra L. & · & . & $\cdot$ & + & $\mathrm{I}^{+}$ \\
\hline Trifolium repens L. & . & $\cdot$ & $\cdot$ & + & $\mathrm{I}^{+}$ \\
\hline
\end{tabular}

Descriptions: 1, 2, 3-Udmurt Republic, Alnashsky district, $5 \mathrm{~km}$ south from village Muvazhi, the coastal shallow water of a pond on the river Golyushurminka, 13.VII.2008, G.R. Platunova; 4-Udmurt Republic, Izhevsk, the neighborhood of the Botanical Garden of Udmurt State University, the damp bottom of the drainage channel, 25.VII.2010, O.A. Kapitonova. 


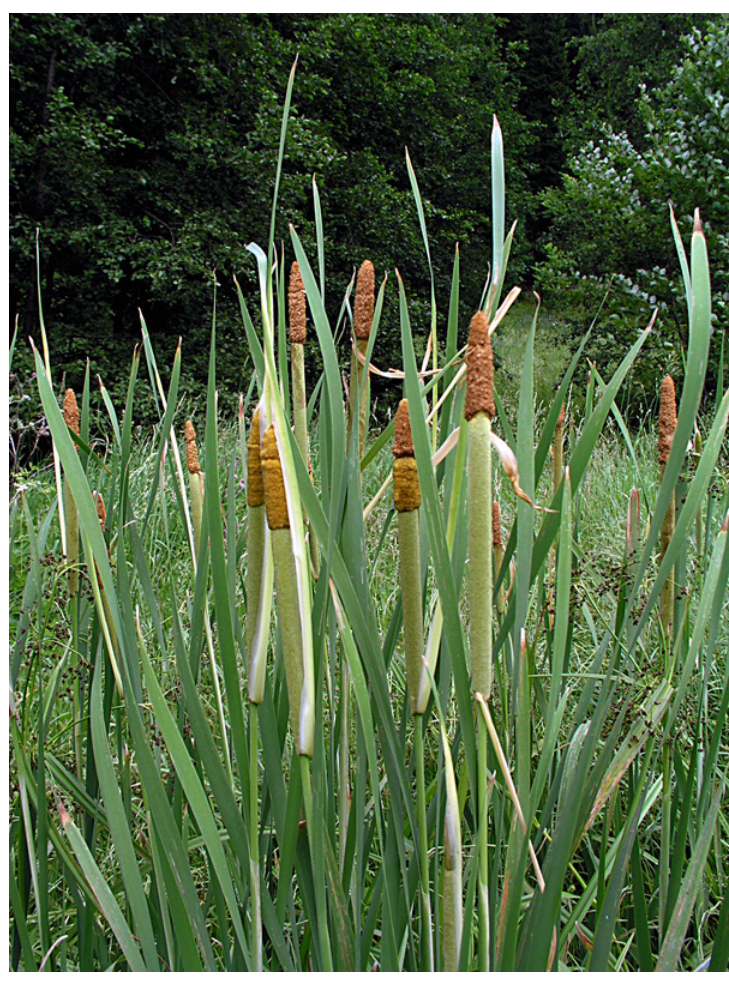

(a)

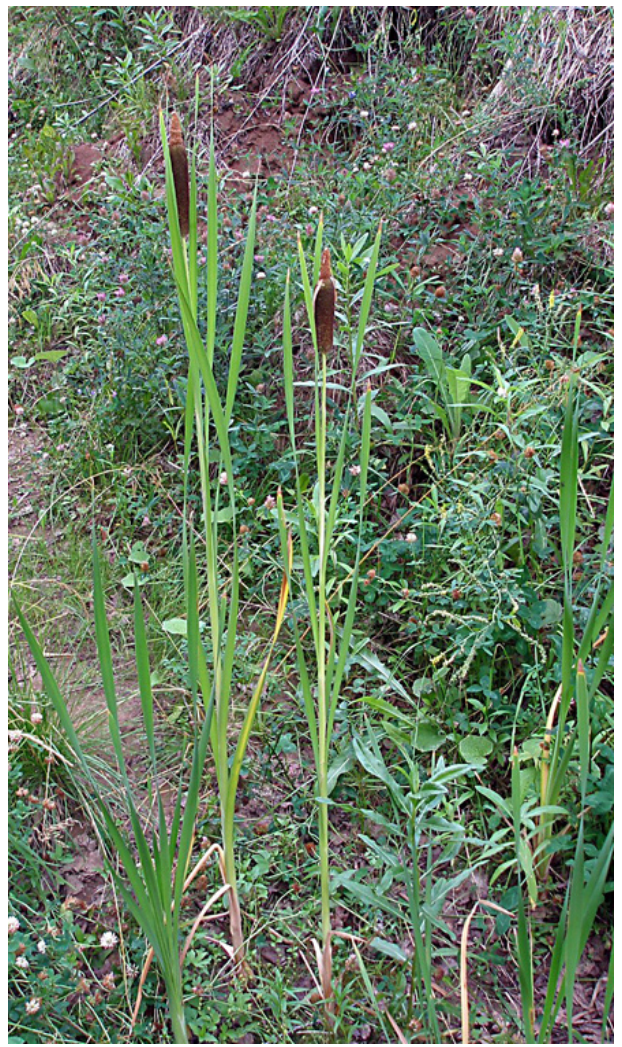

(c)

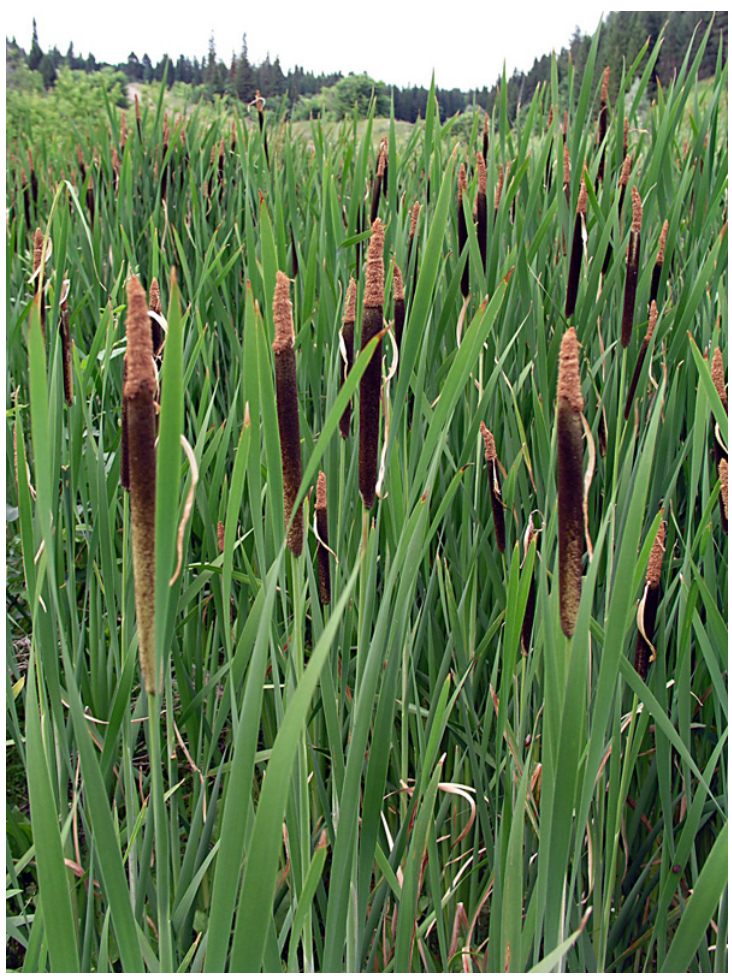

(b)

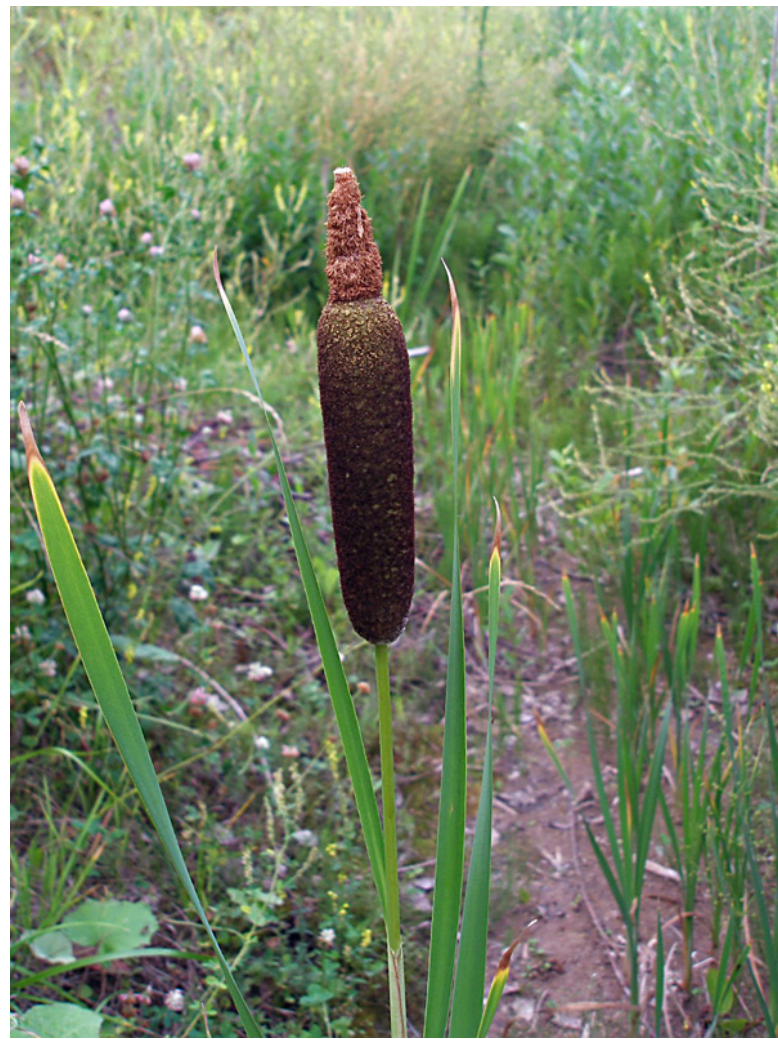

(d)

Figure 2. Typha shuttleworthii W.D.J. Koch et Sond. in VKCU: (a) (b) The population №1 (phases of the flowering and fructification); (c) (d) The population №2 (phase of the fructification). All photos are made V.I. Kapitonov. 
Table 2. Statistical value of morphologic parameters of Typha shuttleworthii W.D.J. Koch et Sond. in VKCU.

\begin{tabular}{cccccc}
\hline Parameters & $\mathrm{N}$ & $\mathrm{M} \pm \mathrm{m}$ & Lim (min - max) & $\sigma$ & CV, \% \\
\hline Height of the reproductive shoot, $\mathrm{m}$ & 57 & $1.35 \pm 0.07$ & $1.07-1.62$ & 0.21 & 15.56 \\
Number of leaves on the reproductive shoot & 437 & $7.67 \pm 0.17$ & $7-8$ & 0.50 & 6.52 \\
Width of media leave of the reproductive shoot, $\mathrm{cm}$ & 171 & $14.01 \pm 1.08$ & $9.90-20.16$ & 3.23 & 23.06 \\
Length of the female inflorescence, $\mathrm{cm}$ & 57 & $16.44 \pm 2.01$ & $11.70-29.00$ & 6.04 & 36.74 \\
Thickness of the female inflorescence, $\mathrm{mm}$ & 57 & $14.44 \pm 1.38$ & $10.00-20.00$ & 4.13 & 28.60 \\
Length of the male inflorescence, $\mathrm{cm}$ & 57 & $6.98 \pm 0.32$ & $5.70-8.00$ & 0.97 & 13.90 \\
Thickness of the male inflorescence, $\mathrm{mm}$ & 57 & $12.11 \pm 2.80$ & $8.00-16.00$ & 2.80 & 23.12 \\
\hline
\end{tabular}

phases - brown with a slightly whitish tinge due to the long hairs of perianth protruding from the stigmas. The latter feature is particularly clearly pronounced in the lower part of the female inflorescence (Figure 2). The gap between female and male inflorescences is absent; the ratio of female inflorescences to male varies from 2.05 to 3.63, an average of 2.36 .

According to the received materials, the morphometric characteristics of the plants of the studied population in general are consistent with literature data. However, we have noticed that some of the plants in the population had larger sizes that it was reflected in the value of some parameters. For example, the average values of the width of the leaf blade and the length of female inflorescence in the studied population were a bit larger than those values, which are given for this species in the literature [2] [3] [7] [8]. It suggests the genetic heterogeneity of the studied population. Perhaps we are not dealing with one species and with a set of populations of $T$. shuttleworthii and hybrid plants generated by crossing $T$. shuttleworthii with closely related species (for example, Typha latifolia L.) in the contact zone of their areas. To a certain extent it is confirmed by our recent finding of a very rare hybrid Typha $\times$ argoviensis Hausskn. ex Asch. et Graebn. (T. latifolia $\times$ T. shuttleworthii) on the territory of Izhevsk [17]. The correctness of this assumption will test subsequent more detailed studies using cytological and molecular genetic methods.

Our research allows us to recognize the low competitive potential of populations of $T$. shuttleworthii, located at the eastern limit of distribution in general. This feature does not allow this species populate primary ecotopes where the ecological niches are already occupied by the structural and functional analogs. The possibilities to populate the secondary ecotopes are also limited, because it superseded from there by stronger competitors, primarily, T. latifolia. Contemporary large-scale anthropogenic transformation of landscapes is threatened by the destruction, transformation and pollution of habitats $T$. shuttleworthii, the consequence of which could be the disappearance of populations of this species or their genetic assimilation with a closely related species.

\section{Conclusion}

T. shuttleworthii-one of the plant species which requires protection on the territory of the VKCU, is $a$ vulnerable species. It cannot compete with other semi-aquatic plants. Anthropogenic changes of the aquatic landscapes may lead to the extinction of this species in the European part of Russia. To save the eastern part of the area of $T$. shuttleworthii, it is necessary to take under protection its populations within the VKCU and to include it in the Red Books of the Udmurt Republic and Tatarstan as vulnerable species.

\section{References}

[1] Riedl, H. (1970) Typhaceae. In: Flora Iranica, Akademische Druck-u.Verlagsanstalt, Graz, Vol. 71/30, 1-8.

[2] Leonova, T.G. (1979) The Family of Typhaceae. In: Fedorov, A.A., Ed., Flora of European Part of the USSR, Vol. 4, Nauka, Leningrad, 326-330.

[3] Heiny, S. and Sytnic, K.M., Eds. (1993) Macrophytes-An Indicators of Environmental Change. Naukova Dumka, Kiev.

[4] (1993) Convention on the Conservation of European Wildlife and Natural Habitats, Concluded at Berne on 19 September 1979. United Nations, Treaty Series, Vol. 1704, A-21159, № 21159, 374-403.

[5] Käsermann, C.V. (1999) Typha shuttlevorthii W.D.J. Sond. In: Käsermann, C.V. and Moser, D.M., Eds., Fiches pratiques pour la conservation, Plantes á fleurs et fougères, Berne, 286-287.

[6] Ondrášek, I. (2002) Recent Occurrence of Some Rare and Endangered Species of Vascular Plants in Southwestern 
Slovakia. Bulletin Slovenskej Botanickej Spoločnosti Bratislava, 24, 133-138.

[7] Uhrin, S. and Bača, F. (2005) A New Locality of Typha shuttlevorthii in Slovakia. Biologia, 60, 105.

[8] Kozłowska, K., Nobis, A. and Nobis, M. (2011) Typha shuttleworthii (Typhaceae), New for Poland. Polish Botanical Journal, 56, 299-305.

[9] Bilz, M., Kell, S.P., Maxted, N. and Lansdown, R.V. (2011) European Red List of Vascular Plants. Publications Office of the European Union, Luxembourg.

[10] Parfenov, V.I., Ed. (2013) Flora of Belarus. Vascular Plants. Vol. 2, Liliopsida, Belarusian Science, Minsk.

[11] Mavrodiev, E.V. (1999) Morphological and Biological Features and Variability of the Cattails (Typha L.) of Russia. Ph.D. Thesis Abstract, Moscow.

[12] Mavrodiev, E.V. and Majorov, S.R. (1999) Floristic Records in Central and North-Western Regions of East Europe. Bulletin of Moscow Society of Naturalists. Biological Series, 6, 61-62.

[13] Tzvelev, N.N. (2006) Typhaceae Juss. In: Menitsky, Y.L. and Popova, T.N., Eds., Synopsis of the flora of the Caucasus, Vol. 2, St. Petersburg, 246-248.

[14] Kapitonova, O.A., Kapitonov, V.I., Dyukina, G.R. and Tukmanova, S.R. (2009) New and Rare Plant Species for Vyatka-Kama Region. Bulletin of Moscow Society of Naturalists. Biological Series, 3, 59.

[15] Kapitonova, O.A., Platunova, G.R. and Kapitonov, V.I. (2012) The Cattails of Vyatka-Kama Region: Monograph. Publishing House of Udmurt University, Izhevsk.

[16] Kapitonova, O.A. and Shkljaeva, S.O. (2012) A New Interesting Finds of Aquatic Macrophytes in Vyatka-Kama Region. Proceedings of the Samara Scientific Center of RAS, 1, 1759-1761.

[17] Kapitonova, O.A., Kalentyeva, E.S. and Altyntsev, A.V. (2014) New Data on Aquatic Flora of Udmurt Republic. Bulletin of Moscow Society of Naturalists. Biological Series, 1, 72-73. 
Scientific Research Publishing (SCIRP) is one of the largest Open Access journal publishers. It is currently publishing more than 200 open access, online, peer-reviewed journals covering a wide range of academic disciplines. SCIRP serves the worldwide academic communities and contributes to the progress and application of science with its publication.

Other selected journals from SCIRP are listed as below. Submit your manuscript to us via either submit@scirp.org or Online Submission Portal.
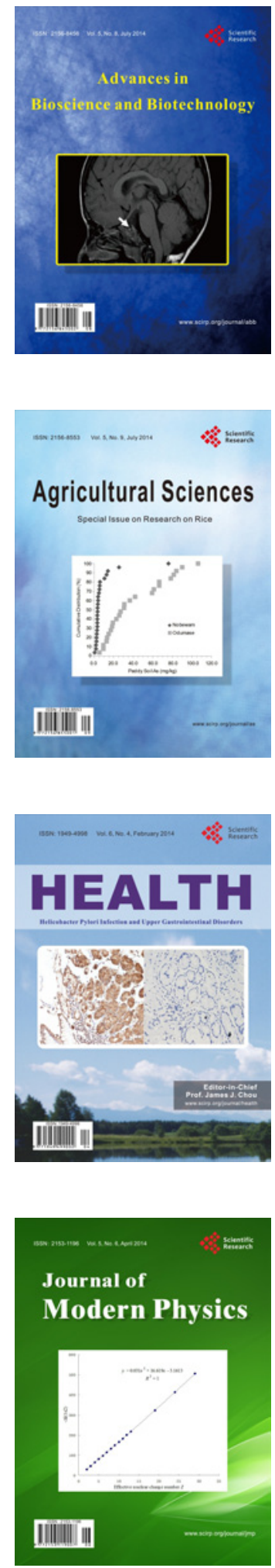
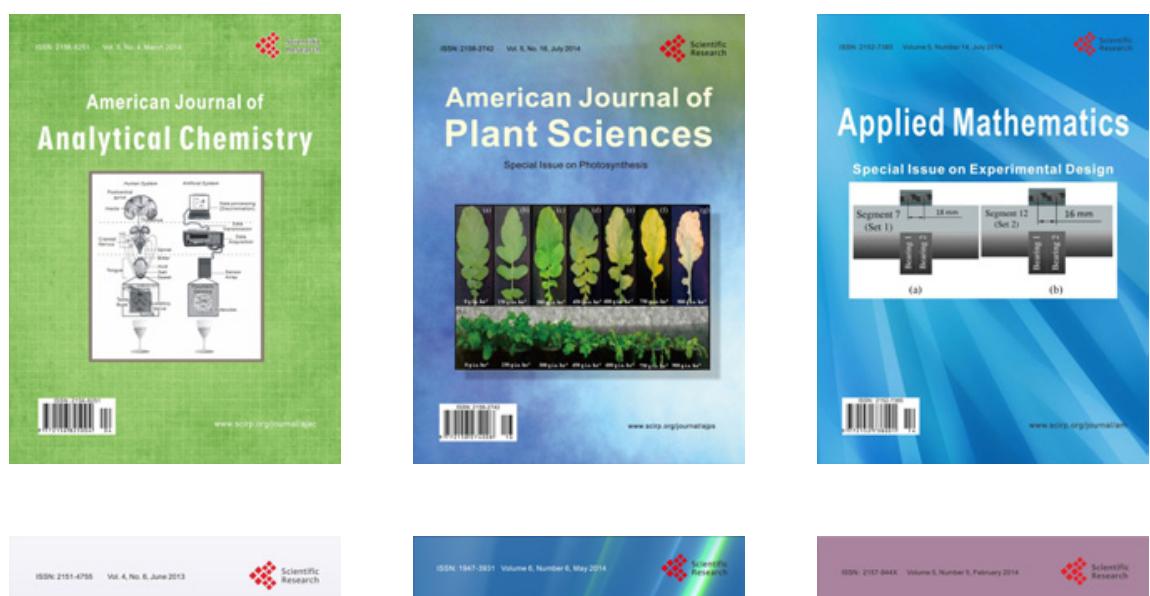

Creative Education
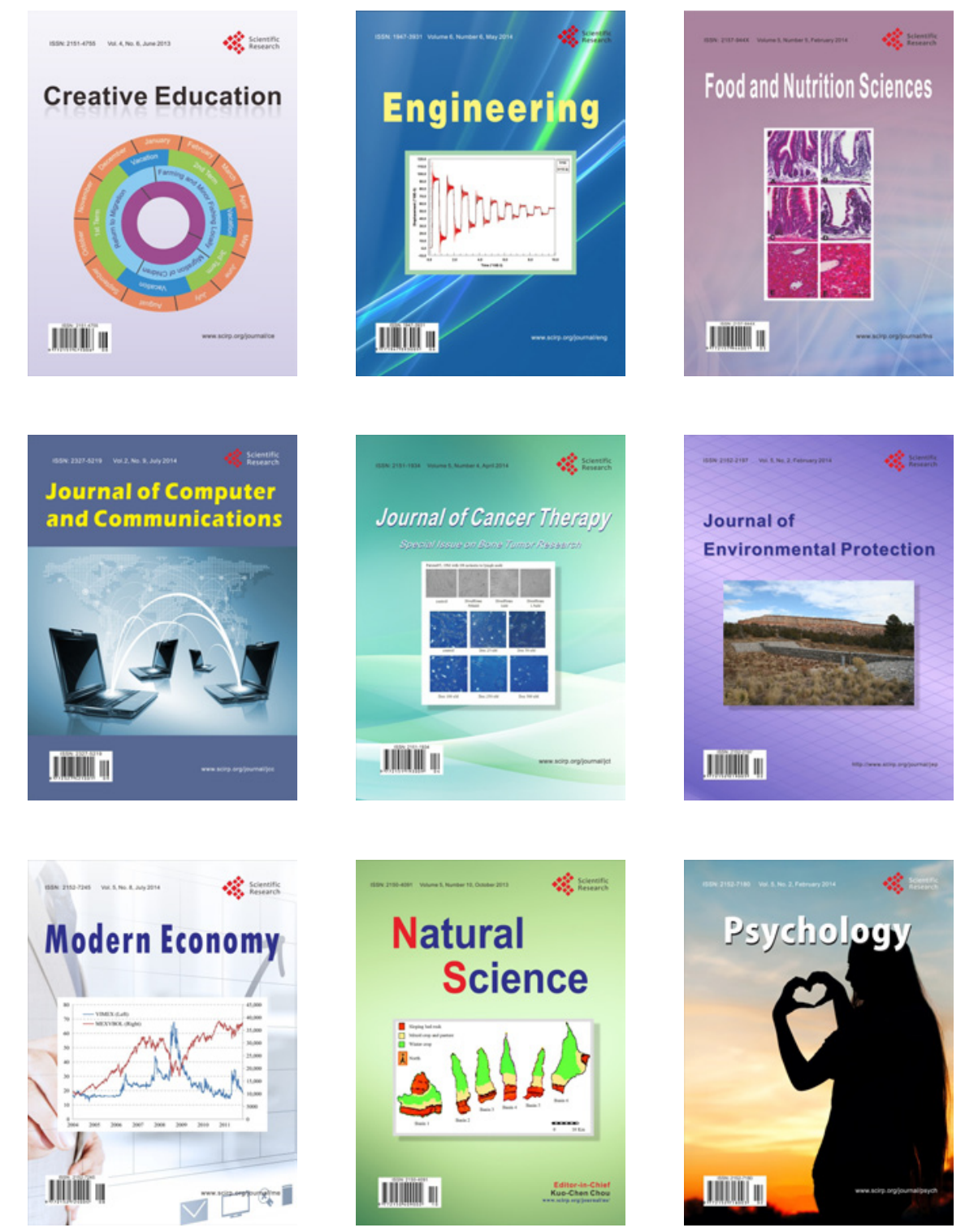